\title{
The Relationship between the Conflicts and the Conflict Management Styles of Police Officers in the Philippines
}

\author{
Xyra Rose A. Galman'1, Sheena Mai A. Galman² ${ }^{\mathbb{D}}$, Jocelyn B. Cruz ${ }^{3}$, Mercedes D. Santos4 \\ ${ }^{1}$ Graduate School, Nueva Ecija University of Science and Technology, Cabanatuan City, Philippines \\ ${ }^{2}$ College of Education, Nueva Ecija University of Science and Technology, Cabanatuan City, Philippines \\ ${ }^{3}$ Graduate School, Nueva Ecija University of Science and Technology, Cabanatuan City, Philippines \\ ${ }^{4}$ College of Management and Business Technology, Nueva Ecija University of Science and Technology, \\ Cabanatuan City, Philippines \\ Email: xyrarose.galman@gmail.com, sheenamaiagalman@gmail.com
}

How to cite this paper: Galman, X.R.A., Galman, S.M.A., Cruz, J.B. and Santos, M.D. (2021) The Relationship between the Conflicts and the Conflict Management Styles of Police Officers in the Philippines. Open Access Library Journal, 8: e7540. https://doi.org/10.4236/oalib.1107540

Received: May 18, 2021

Accepted: June 6, 2021

Published: June 9, 2021

Copyright $\odot 2021$ by author(s) and Open Access Library Inc.

This work is licensed under the Creative Commons Attribution International License (CC BY 4.0).

http://creativecommons.org/licenses/by/4.0/

\begin{abstract}
This study analyzed the relationship between the conflicts encountered by the Police Non-Commissioned Officers (PNCO) and Police Commissioned Officers (PCOs) in a province in the Philippines and the conflict management styles of the latter. The descriptive-correlation research design was used in this study involving 153 PNCOs and 24 PCOs as respondents. The conflicts were categorized as Controversy, Conceptual, and Conflict of Interest. On the other hand, the management styles were compromise, competition, and collaboration. Based on the results of the study, the management style of the respondents based on the given situations of conflict resulted in the following: PCOs employed competition in resolving controversies while they used compromise in resolving conceptual conflicts and conflict of interest. The conflicts encountered were significantly correlated with the management style of the respondents in different situations of conflict such as controversy, conceptual, and conflict of interest.
\end{abstract}

\section{Subject Areas}

Management Organization

\section{Keywords}

Conflict, Conflict Management Styles, Controversy, Conceptual, Conflict of Interest

\section{Introduction}

A conflict is a doubt or a questioning, opposition, incompatible behavior, con- 
troversy or antagonistic interaction and dispute is one of the ranges of events (Brown, et al., 1993) [1]. In addition, a conflict is a dispute that exists when a claim or assertion made by one party is rejected by the other party and that rejection is not accepted (Kumaraswamy \& Yogeswaran, 1998) [2]. This shows that disputes more likely occur when the conflicting parties show an action or arguments to a controversy.

Another set of sources is the one which Smith (1992) [3] describes as difficulties among individuals that break personal and professional relationships and reduce effectiveness at work. That is, conflict produces tension and distracts team members from performing the task (Wall \& Callister, 1995) [4]. In addition to this are the conflict of interest and the conceptual conflict (Aldag \& Kuzuhara, 2002) [5]. The former occurs when there is interference on one's goals by another's personal goals. The latter occurs when there is the compatibility of ideas.

In any of the above conditions and or situations, managers, supervisors, and administrators play a vital role in coming up with a fruitful resolution of conflict. They are responsible for making indifferences a source of challenges or opportunities wherever there are choices to be made. Supervisors may have to act as mediators and arbitrators from time to time. Mediation can help in maintaining responsibility for problem-solving and conflict resolution at the level of those who own the challenge. Also, mediation by an outside mediator is material for preventing conflicts over common resources and promoting cooperation (Kydd 2006) [6]. Failure to cooperate without credible punishment threats leads to lesser payouts for the "losing" party (Eisenkopf \& Bachtiger, 2013) [7] Regardless of whoever the mediator is, such acts of resolving conflict form part of conflict management.

According to Johnson (1996) [8], conflict management refers to the long-term management of intractable conflicts. It is the label for the variety of ways by which people handle grievances-standing up for what they consider to be right and against what they consider to be wrong. Those ways include such diverse phenomena as gossip, ridicule, lynching, terrorism, warfare, feuding, genocide, law, mediation, and avoidance. It can therefore be deduced that the forms of conflict management that will be used in any given situation can be somewhat predicted and explained by the social structure-or social geometry-of the case.

The Philippine National Police (PNP), being the agency entrusted for public safety and management coordinates with both public and private sectors be it in community and industry. As such they are expected to effectively perform their responsibilities. What the agency stands as an organization is reflected by how effectively it does its part in the community. However, like any organization, the PNP encounters conflicts, as shown by mass media forecasting police-to-police and police-to-inmates conflict and cases against one another.

The Chief of Police (COP) and other Police Commissioned Officers (PCO) often dealt with the conflicts among Police Non-Commissioned Officers (PNCO), 
inmates under custody as well, and sometimes among fellow PCOs from other municipalities and cities and stakeholders. These conflicts need to be resolved for them to do their responsibilities without additional burden in mind. Hence, in this part, an effective management style will result in a harmonious relationship among the public and private sector, the business sector as such. Ineffective management will, otherwise, result in poor partnership and interrelationship in any sector. Hence, it is of great interest to know the conflict management styles of the PCOs and their relationship with the PNCOs extent of encountered conflicts.

\section{Methods}

\subsection{Research Design}

The descriptive-correlational study was used in this study to determine the relationship between the extent of the different conflicts encountered by the policemen-respondents (PNCO) and the conflict management styles of the police manager respondents (PCO).

\subsection{Sampling and Sampling Technique}

This study involved 153 Police Non-Commissioned Officers (PCO) and 24 Police Commissioned Officers (PNCO) as respondents, taken from eight (8) police stations in the province. The number is sufficient $(n>100)$ since this is a bivariate analysis. The former were the policemen, selected using simple random sampling while the latter were the police station managers, selected using purposive sampling. In selecting the PCOs purposive sampling was employed since they were the target respondents to represent the management or administration of the police station. Also, the PNCOs were considered to be respondents since they were the ones directly involved with the conflict and that they were the actual persons who can provide clear data to solve the problems of this study.

Table 1 shows the demographic profile of the respondents.

The table shows that most of the PNCOs were age 31 - 40 years old, and majority were male, and college graduate. On the other hand, $50 \%$ of PCOs were 31 40 years old, majorities were male and most of them were Master's degree graduate.

\subsection{Research Instrument Used}

The principal instrument in gathering the pertinent data for the study was a questionnaire, the contents of which were based on the arguments of Aldag and Kuzura (2002) about organizational behavior and management. The questionnaire is of two (2) parts. Part I solicited data as regards the profile of the respondents, both for the PCOs such as the Chief-of-Police and Deputy Chief of Police and Chief Section Officers and PNCOs. Part II of the instrument was divided into two sub-parts written side by side of the different conflicts identified by the 
Table 1. Demographic profile of the respondents.

\begin{tabular}{|c|c|c|c|c|c|}
\hline \multicolumn{2}{|c|}{ Demographic Profile } & \multicolumn{2}{|c|}{ PNCO } & \multicolumn{2}{|c|}{ PCO } \\
\hline \multirow{4}{*}{ Age } & $21-30$ & 50 & $32.68 \%$ & 8 & $33.33 \%$ \\
\hline & $31-40$ & 69 & $45.10 \%$ & 12 & $50.0 \%$ \\
\hline & $41 \&$ above & 34 & $22.22 \%$ & 4 & $16.67 \%$ \\
\hline & Total & 153 & $100.0 \%$ & 24 & $100.0 \%$ \\
\hline \multirow{3}{*}{ Sex } & Male & 113 & $73.85 \%$ & 17 & $70.83 \%$ \\
\hline & Female & 40 & $26.14 \%$ & 7 & $29.17 \%$ \\
\hline & Total & 153 & $100.0 \%$ & 24 & $100.0 \%$ \\
\hline \multirow{4}{*}{$\begin{array}{c}\text { Highest } \\
\text { Educational } \\
\text { Attainment }\end{array}$} & College Graduate & 145 & $94.77 \%$ & 6 & $25.0 \%$ \\
\hline & Master's Degree (units) & 5 & $3.27 \%$ & 8 & $33.33 \%$ \\
\hline & Master's Degree Graduate & 3 & $1.96 \%$ & 10 & $41.67 \%$ \\
\hline & Total & 153 & $100 \%$ & 24 & $100.00 \%$ \\
\hline
\end{tabular}

researcher. The first sub-part on the left side of the table solicited the respondents' assessment as regards the extent to which the different conflicts arise within the three (3) identified areas or sources of conflict namely controversy, conflict of interest, and conceptual. The second subpart at the right side of the table determined the conflict management strategy adopted by police station managers (PCO) in resolving each of the identified conflicts.

The draft form of the instrument was checked by experts in assessment and instrumentation, and officials of the PNP. Subsequent revision was done. Thereafter the revised, form was administered to a group of respondents with same characteristics as the samples under study. The reliability index of 0.92 was computed using KR-20.

\section{Results and Discussions}

\subsection{Description of the Extent of the Different Conflicts Encountered by the Policemen-Respondents (PNCO)}

The extent of different conflicts was described in terms of controversy, conceptual, and conflicts of interest.

Table 2 shows the assessment of the extent of the different conflicts encountered by the policemen-respondents.

Note that the conflicts in terms of controversy were described as of moderate extent, having a grand mean of 3.04. Only one of the conflicts enumerated was of low extent. That is, giving comments using libelous words within the police station and when everyone could hear. On the other hand, the act of discussing the same subject matter with the same police officers but of conflicting interpretation of theories; giving various answers to the same question or problem during a conference or meeting with police officers and personnel; and being though involved with issues on police morality and decency were of moderate extent. 
Table 2. Assessment of different conflicts in terms of controversy.

\begin{tabular}{cccc}
\hline Level & $\mathrm{f}$ & $\%$ & Grand Mean \\
\hline Moderate Extent & 9 & $90 \%$ & 3.04 \\
Low Extent & 1 & $10 \%$ & (Moderate Extent) \\
Total & 10 & $100 \%$ & \\
\hline
\end{tabular}

Evidently, there was a moderate extent of the conflict involving incompatibility of ideas in the organization. This can be supported by Aldag and Kuzura (2002) [5] as they defined controversy as indifferences on people's ideas, information, conclusions, theories, and opinions. However, when managed constructively, such can facilitate high-quality decision making in the organization.

Situations under controversy include those that relate to ideas and controversial issues like morality. This also relate to opinions on issues that may malign or hurt the feelings of others.

Table 3 shows the assessment of the extent of the different conflicts encountered by the policemen-respondents.

The conflicts in terms of aspect were found to be of moderate extent, having a grand mean of 3.01. Resistance to comments and suggestions; having incompatible ideas and suggestions during meetings/conference; being uncooperative regarding police programs and projects; and insisting of being always right because of having it a practice for a long time were of moderate extent. However, talking about superior's decision regarding another police officer that was disclosed to public knowledge was of great extent. The findings of the study can be supported by Aldag and Kuzuhara (2002) [5] as these situations fit their description of conceptual conflict. That is, a person experiences conceptual conflict when incompatible ideas exist simultaneously in his or her mind or when information being received does not seem to fit with what one already knows. An individual experience conceptual conflict when engaged in controversy as ideas and arguments are presented that are incongruent with one's original position.

Situations with conceptual conflict include those that are not compatible with one's position. They pose conflicts when they believe otherwise and tend to express their disagreement on a particular issue.

Table 4 shows the assessment of the extent of the different conflicts encountered by the policemen-respondents.

Conflict of interests includes those that relate to name calling, insults, or aggressive behavior of fellow officers. They tend to interfere or block others in the pursuit of individual goals. Here, the grand mean of 2.98 implies that this type of conflict was of moderate extent.

Not making use of police resources to maximum effectiveness even if they are available for effective program/activity/outcome, and conducting police program and operations that coincides with other police officer's program and activities were of great extent. On the other hand, always listening to "hearsay" and thinks that they are always the subject of a negative conversation was of low extent. 
Table 3. Assessment of different conflicts in terms of conceptual.

\begin{tabular}{cccc}
\hline Level & $\mathrm{f}$ & $\%$ & Grand Mean \\
\hline Great extent & 1 & $10 \%$ & 3.01 \\
Moderate extent & 9 & $90 \%$ & (moderate extent) \\
Total & 10 & $100 \%$ & \\
\hline
\end{tabular}

Table 4. Assessment of different conflicts in terms of conflict of interest.

\begin{tabular}{cccc}
\hline Level & f & $\%$ & Grand Mean \\
\hline Great extent & 2 & $20 \%$ & \\
Moderate extent & 7 & $70 \%$ & 2.98 \\
Low extent & 1 & $10 \%$ & (moderate extent) \\
Total & 10 & $100 \%$ & \\
\hline
\end{tabular}

Moreover, working more for personal attainment of goals rather than for the organization; being envious of the achievements of the others because of lack of the ability to do the same; refusal to acknowledge the assistance provided by colleagues; harassing the relatives of fellow officers were fund to be of moderate extent.

All in all, the results of the study were reflected in the paper of Aldag and $\mathrm{Ku}$ zuhura (2002) [5]. According to them, conflict of interest occurs when the actions of one person attempting to maximize his or her goals prevent, block, or interfere with another person attempting to maximize personal goals. This includes control over resources, preferences over activities, and a range of relationship issues that often result in name calling, insults, threats, or physical aggression.

\subsection{Conflict Handling Strategies Applied by the Police Manager-Respondents (PCO) in Dealing with the Different Conflicts}

Table 5 shows the conflict-handling strategies applied by the PCOs in dealing with conflict in terms of controversy.

Note that the overall weighted mean of 3.39 implies that the PCOs applied competition as a management style in dealing controversy-based conflicts. Competition is the exercise of power to assert one's position. It is a way of standing for one's right and what he/she believes is correct.

Among the situations in which competition were applied were: whenever the members of the organization are undecided on issues and police situation matters; speaking of private life and concerns of other policemen and community members; and discussing in public the confidential matters of police officers and/or persons under custody (inmates). On the other hand, collaboration was applied in giving various answers to the same question or problem during a conference or meeting with police officers and personnel. Compromise was applied in discussing the same subject matter with the same police officers but of 
Table 5. Conflict-handling strategies in terms of controversy.

\begin{tabular}{cccc}
\hline Management Style & F & $\%$ & Grand Mean \\
\hline Compromise & 3 & $30 \%$ & \\
Collaboration & 1 & $10 \%$ & 3.39 \\
Competition & 6 & $60 \%$ & (Competition) \\
Total & 10 & $100 \%$ & \\
\hline
\end{tabular}

conflicting interpretation of theories as well as in giving comments using libelous words within the police station and when everyone could near.

Table 6 shows the conflict-handling strategies applied by the PCOs in dealing with conflict in terms of controversy.

The table indicates that the PCOs applied compromise in handling conceptual-related conflicts, with an overall weighted mean of 3.56. To compromise means to negotiate. It is finding a way of coming up with a mutually acceptable solution to a conflict. It is also seeking a middle ground solution.

Specifically, such strategy was applied in some of these cases: talking about superior's decision regarding another police officer that was disclosed to public knowledge, having incompatible ideas and suggestions during meetings/conferences; and insisting that they were right because it has been their practice for a long time. On the other hand, competition was applied in these cases: resistance to comments and suggestions; and police officers seeking for recognition and feel unworthy when not given. Lastly, collaboration was applied in uncooperative regarding police programs and projects.

Table 7 shows the conflict-handling strategies applied by the PCOs in dealing with conflict in terms of controversy.

Based on the table, the PCOs applied compromise in dealing with conflict of interest in their organizations, with an overall mean of 3.87. To compromise in this case implies to arrive at a neutral ground where both parties can accept a common solution to solve a conflict. In particular, the PCOs applied compromise in not making use of police resources to maximum effectiveness even if they are available for effective program/activity/outcome; conducting police program and operations that coincides with other police officer's program and activities; and refusing to acknowledge the assistance provided by colleagues because they think they are better and older. They also applied competition in working more for personal attainment of goals rather than of the organization; and always listening to "hearsay" and thinks that they are always the subject of a negative conversation. The results of the study can be supported by Vokić and Sontor (2009) [9], as they argued in their paper that one of the most used conflict management strategies is compromising.

\subsection{Significant Relationship between Extent of the Different Conflicts Encountered by the PNCOs and the Conflict Management Styles of the PCOs}

Table 8 shows the test of significant relationship between the extent of the different 
Table 6. Conflict-handling strategies in terms of conceptual.

\begin{tabular}{cccc}
\hline Management Style & F & $\%$ & Overall Weighted Mean \\
\hline Compromise & 6 & $60 \%$ & \\
Collaboration & 1 & $10 \%$ & 3.56 \\
Competition & 3 & $30 \%$ & (Compromise) \\
Total & 10 & $100 \%$ & \\
\hline
\end{tabular}

Table 7. Conflict-handling strategies in terms of conflict of interest.

\begin{tabular}{cccc}
\hline Management Style & F & $\%$ & Overall Weighted Mean \\
\hline Compromise & 4 & $40 \%$ & \\
Collaboration & 3 & $30 \%$ & 3.87 \\
Competition & 3 & $30 \%$ & (Compromise) \\
Total & 10 & $100 \%$ & \\
\hline
\end{tabular}

Table 8. Test of significant relationship between extent of the different conflicts encountered by the PNCOs and the conflict management styles of the PCOs.

\begin{tabular}{ccc}
\hline Conflict & $\mathrm{R}$ & p-value \\
\hline Controversy & $0.330^{*}$ & 0.002 \\
Conceptual & $0.637^{*}$ & 0.000 \\
Conflict of Interest & $0.584^{*}$ & 0.000 \\
\hline
\end{tabular}

${ }^{\star}$ Correlation significant at 0.01 level (2-tailed).

conflicts encountered by the PNCOs and the conflict management styles of the PCOs.

Based on the Pearson correlation coefficient of 0.330 , significant at 0.00 , for controversy, there is a significant relationship between extent of the different conflicts encountered and the conflict management styles.

Under conceptual conflict, the strength of the relationship between extent of conflicts encountered and the management styles is also moderate. It has an $r$ value of 0.637 with a $p$ value of 0.00 .

With conflict of interest, the relationship between extent of problems encountered and management style is significant with an $r$ value of 0.584 , with a $p$ value of 0.00 . The strength of the relationship is also moderate.

The findings of the study can be supported by Whetten and Cameron (2002) [10] as they posited the effective conflict management style that is highly effective for every situation. Marques, Renato, Dimas \& Rebelo (2015) [11], in their paper, set in the framework of relating the types of conflict (task and relationship) with conflict management strategies (integrating, dominating compromising, obliging and avoiding). Moreover, the results of the study are corollary to the contingency perspective. According to this perspective, there is an appropriate type of strategy that is appropriate for every situation and requires a specific response (Dimas \& Lawrence, 2011 [12]; Rahim, 2001 [13]). 


\section{Conclusions and Recommendations}

Policemen are exposed to different situations where conflicts arise. The findings show the categories of conflicts on the following: controversy, conceptual, and conflicts of interest. Situations under controversy include those that relate to ideas and controversial issues like morality. This also relates to opinions on issues that may malign or hurt the feelings of others. Situations with conceptual conflict include those that are not compatible with one's position. They pose conflicts when they believe otherwise and tend to express their disagreement on a particular issue. Conflict of interests includes those that relate to name-calling, insults, or aggressive behavior of fellow officers. They tend to interfere or block others in the pursuit of individual goals.

The police officers' conflict management styles were competition for situations under controversy; compromise for conceptual conflicts and conflicts of interests.

There is a significant relationship between the extent of the different conflicts encountered and the conflict management styles.

Based on the conclusions formulated, the results of the study may be used as a reference in the future formulation of policies and procedures on conflict management which would benefit all concerned in the field of law enforcement as well as the local government units and the community in dealing with the conflicts discussed herein. Also, the same results may be used as a basis for the conduct of a seminar for police station managers on handling conflict among policemen to create a conflict-free police station. Moreover, since the study is limited on the relationship between the conflicts encountered by the PNCOs and the management styles of the PCO, another study may be conducted to determine which among the management styles is the most effective in dealing with the conflicts.

\section{Conflicts of Interest}

The authors declare no conflicts of interest regarding the publication of this paper.

\section{References}

[1] Shipman, S., Waters, B., et al. (1993) Brown \& Marriott's ADR Principles and Practice. Sweet and Maxwell, London.

[2] Kumaraswamy, M. and Yogeswaran, K. (1998) Significant Sources of Construction Claims. International Construction Law Review, 15, 144-160.

[3] Smith, M. (1992) Facing up to Conflict in Construction. Paper Presented at the First International Conference on Construction Conflict. Management and Resolution, Manchester, 25-27 September 1992, 26-33.

[4] Wall Jr., J.A. and Callister, R.R. (1995) Conflict and Its Management. Journal of Management, 21, 515-558. https://doi.org/10.1177/014920639502100306

[5] Aldag, R. and Kuzuhara, L. (2002) Organizational Behavior and Management: An Integrated Skills Approach. South-Western Thomson Learning, Cincinnati, $\mathrm{OH}$.

[6] Kydd, A.H. (2006) When Can Mediators Build Trust? American Political Science Re- 
view, 100, 449-462. https://doi.org/10.1017/S0003055406062290

[7] Eisenkopf, G. and Bachtiger, A. (2013) Mediation and Conflict Prevention. Journal of Conflict Resolution, 57, 570-597. https://doi.org/10.1177/0022002712448910

[8] Johnson, R. (1996) Management, Systems, and Society: An Introduction. Goodyear Pub. Co., Los Angeles, California.

[9] Vokić, N.P. and Sontor, S. (2009) Conflict Management Styles in Croatian Enterprises-The Relationship between Individual Characteristics and Conflict Handling styles. EFZG Working Papers Series 0905, Faculty of Economics and Business, University of Zagreb, Zagreb, Croatia.

[10] Whetten, D. and Cameron, K. (2002) Developing Management Skills. 5th Edition, Prentice-Hall, Upper Saddle River, NJ.

[11] Marques, F., Lourenço, P.R., Dimas, I.D. and Rebelo, T. (2015) The Relationship between Types of Conflict, Conflict Handling Strategies and Group Effectiveness. http://www.cieo.pt/journal/J_1_2015/article5.pdf

[12] Dimas, I.D. and Lourenço, P. (2011) Conflitos e gestão de conflitos em contexto grupal. In: Gomes, A.D., Ed., Psicologia das organizaçôes, do trabalho e dos recursos humanos, Imprensa da Universidade de Coimbra, Coimbra, 201-240. https://doi.org/10.14195/978-989-26-0238-7_4

[13] Rahim, M.A. (2001) Managing Conflict in Organizations. 3rd Edition, Quorum Books, Westport, Connecticut. 